\title{
Effect of Heat Treatment on Electrical and Mechanical Properties of the Solid Sapropel
}

\author{
Andris Martinovs ${ }^{1}$, Rasma Tretjakova ${ }^{1}$, Rene Castro ${ }^{3}$, Vladimir Solovyev ${ }^{4}$, \\ Josef Timmerberg ${ }^{2}$, Alexander Cvetkov ${ }^{4}$, Sergey Gango ${ }^{4}$, Angelika Borkenstein ${ }^{2}$, \\ Paul Beckmann ${ }^{2}$, Helmut Schütte ${ }^{2}$, Nikolai Puchkov ${ }^{4}$, Sergey Trifonov ${ }^{4}$ \\ ${ }^{I}$ Rezekne Academy of Technologies, LV-4601 Rezekne, Latvia \\ ${ }^{2}$ Jade University of Applied Sciences, 26389 Wilhelmshaven, Germany \\ ${ }^{3}$ Herzen State Pedagogical University of Russia, 191186 St. Petersburg, Russia \\ ${ }^{4}$ Pskov State Universities, 180000 Pskov, Russia
}

\begin{abstract}
In this work changes of electrical and mechanical properties (hardness) of the solid sapropel after its heat treatment were researched. Changes of real and imaginary parts of dielectric permittivity, dielectric losses and specific electrical resistance depending on electrical field frequency in the range $0.01 \mathrm{~Hz}-1 \mathrm{MHz}$ were observed. Temperature dependences of $A C$ (at $1 \mathrm{kHz}$ ) and DC electrical conductivity were studied. Chemical sample composition, IR spectra and structure of the solid sapropel were investigated. Heat treatment has a noticeable effect on the electrical characteristics of solid sapropel due to the strong influence of water on the charge transfer in this complex material. Charge transfer occurs predominantly due to ion migration and demonstrates strong dependence upon hydration - dehydration processes. After the heat treatment of the solid sapropel at the temperature of $100^{\circ} \mathrm{C}$ its hardness doesn't change. If the sample of the solid sapropel is subjected to 20 min heat treatment at the temperature of $150^{\circ} \mathrm{C}$, its hardness decreases by $5.4 \%$, the number of $C=C$ bonds decreases by $6.3 \pm 0.1 \%$, the number of $C=N$ bonds decreases by $2.2 \pm 0.1 \%$, the number of $C$ - $C$ bonds decreases by $1,7 \pm 0.1 \%$, the number of $\mathrm{C}-\mathrm{H}$ bonds increases by $18.5 \pm 0.3 \%$. It shows that in the temperature range 100-150 $\mathrm{C}$ destructive processes of the solid sapropel start, although visually (with optical microscope and with SEM) changes of structure are impossible to observe yet.
\end{abstract}

Keywords: solid sapropel, dielectric permittivity, specific electrical resistance, hardness, IR spectra, chemical composition.

\section{INTRODUCTION}

Latvia, Russia's Pskov region, Lithuania, Belarus are rich with lake sediments - sapropel. For example, in Russian Federation the total sapropel reserves exceed 200 billion $\mathrm{m}^{3}$ [15], in Latvia they are approximately 2 billion $\mathrm{m}^{3}$ [11]. Sapropel is renewable resource; its layer in lakes enlarges by 1$2 \mathrm{~mm}$ per year [11]. At present usage of sapropel in production volumes is insignificant; it is used mostly for enrichment of soil, in balneology and cosmetology. Sapropel can be used as binding substance in production of fuel briquettes [12], as adsorbent [12], [13], [14], [21], as biologically active substance [16], [17], [18], as binding substance in the production of thermal and acoustic insulation building materials [24], [25]. Possibly, this resource can have also other usages, which enable to develop products with high added value. Therefore, complex research of mechanical, physical, chemical and biological properties of sapropel is the necessary purpose. Elaboration foreruns in research of mechanical and electrical properties of the solid sapropel were made in work [6], thermal properties are researched in [20]; biological [23], [26], chemical [11], [21], [22], [23], and magnetic [19] properties were also investigated. In order to change properties of material, it is modified. Modification methods of various materials are viewed in work [10].

The purpose of this work is to research changes of electrical and mechanical properties of the solid sapropel after its heat treatment.

\section{II.MATERIALS AND METHODS}

Samples of sapropel were taken from the depth $0.5 \mathrm{~m}$ in the gulf of Diunoklis of the lake Rušons in Latvia and dried in stationary air space with temperature $20^{\circ} \mathrm{C}$ and relative humidity $60-70 \%$ until the solid sapropel was obtained. Material was sawn to $3 \mathrm{~mm}$ thick plane-parallel plates (with Struers Secotom-15 saw), their surfaces were grinded (Struers LaboPol-5 grinding machine; disk MDAllegro, $200 \mathrm{~mm}$, diamond spray in grain sizes from 15- $3 \mu \mathrm{m})$. All samples of the solid sapropel were placed into the thermostat Memmert UNE 400 with temperatures of $20,50,75,100,125$ and $150^{\circ} \mathrm{C}$ for 20 minutes. After cooling at the temperature $20^{\circ} \mathrm{C}$ Shore $\mathrm{D}$ hardness was measured, structure of the material was researched (optical microscope, SEM), chemical composition was determined (SEM), IR spectra were captured and electrical properties were determined.

ISSN 1691-5402

(C) Rezekne Academy of Technologies, Rezekne 2017 http://dx.doi.org/10.17770/etr2017vol3.2611 
Dielectric spectra of the samples under study were investigated within wide frequency range $0.01 \mathrm{~Hz}-$ $1 \mathrm{MHz}$ by dielectric spectrometer "Novocontrol" with high-resolution automatic frequency analyser ALPHA-ANB.

The temperature dependences of all the electrical characteristics of the samples with graphite electrodes were obtained upon continuous heating or cooling with a rate of 1 to 2 degrees per minute. Alternatingcurrent (AC) conductivity and dielectric permittivity were measured by an E7-13 impedance meter at the frequency of $1 \mathrm{kHz}$. Direct current (DC) measurements were carried out by micro ammeters F195 or M95.

\section{RESULTS AND DISCUSSION}

Figure 1 demonstrates frequency dependences of dielectric characteristics (real $\varepsilon$ ' and imaginary $\varepsilon$ " parts of dielectric permittivity, as well as dielectric losses $\tan \delta$ ) measured at room temperature for solid sapropel samples annealed at $20^{\circ} \mathrm{C}$ (curves 1-3) and $100^{\circ} \mathrm{C}$ (curves 4-6). The most striking observation is the pronounced dielectric loss relaxation maximum which can be seen in the low-frequency region: $\tan \delta_{\text {max }} \approx 0.4$ near $f \approx 70 \mathrm{~Hz}$ after the heat treatment at $20^{\circ} \mathrm{C}$ (curve 3 ) and $\tan \delta_{\max } \approx 0.5$ near $f \approx 20 \mathrm{~Hz}$ after the heat treatment at $100^{\circ} \mathrm{C}$ (curve 6). Similar dielectric losses at low frequencies $\left(10^{-3}-10^{2} \mathrm{~Hz}\right)$ are usually referred to migration polarisation which occurs due to charge migration to the grain boundaries or other types of structure inhomogeneity [1].

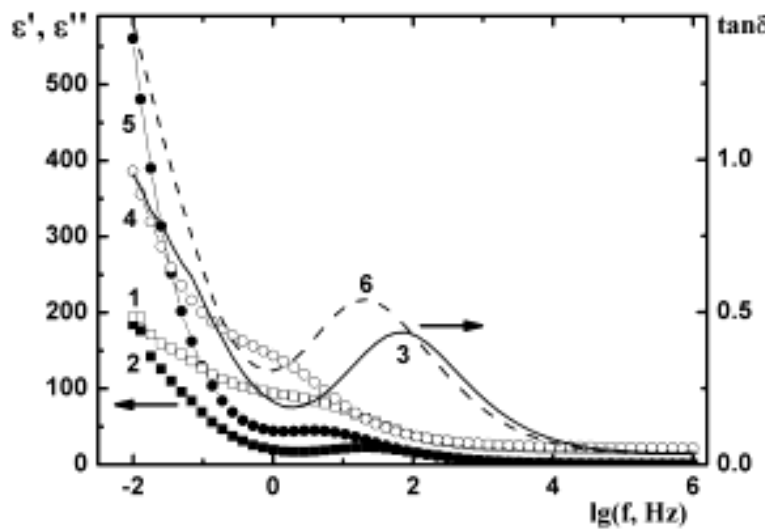

Fig.1. Frequency dependences of the dielectric characteristics measured at room temperature for the sapropel samples after heat treatment at $\mathrm{t}=20^{\circ} \mathrm{C}$ (curves $1-3$ ) and $\mathrm{t}=100^{\circ} \mathrm{C}$ (curves 4-6): real part $\varepsilon$ ' of dielectric permittivity ( 1 - open quadrates, 4 - open circles), imaginary part $\varepsilon$ " of dielectric permittivity (2 - closed quadrates, 5 closed circles), dielectric losses $\tan \delta$ (3 - solid line, 6 - dashed line).

One can also analyse dependence $\varepsilon^{\prime \prime}=\mathrm{F}\left(\varepsilon^{\prime}\right)$, i.e. Cole-Cole plot [2], approximated by [3], [4].

$$
\varepsilon^{\prime}=\varepsilon_{\infty}+\frac{\left(\varepsilon_{c}-\varepsilon_{\infty}\right)\left[1+(\omega \tau)^{1-\alpha} \sin \frac{\pi \alpha}{2}\right]}{1+2(\omega \tau)^{1-\alpha} \sin \frac{\pi \alpha}{2}+(\omega \tau)^{2(1-\alpha)}},
$$

$$
\varepsilon^{\prime \prime}=\frac{\sigma}{\varepsilon_{0} \omega}+\frac{\left(\varepsilon_{c}-\varepsilon_{\infty}\right)(\omega \tau)^{1-\alpha} \cos \frac{\pi \alpha}{2}}{1+2(\omega \tau)^{1-\alpha} \sin \frac{\pi \alpha}{2}+(\omega \tau)^{2(1-\alpha)}}
$$

where $\varepsilon_{\mathrm{c}}$ and $\varepsilon_{\infty}$ are the values of dielectric permittivity at low $(\omega \cdot \tau<<1)$ and high $(\omega \cdot \tau>>1)$ frequencies, respectively, $\sigma$ represents DC electric conductivity, $\varepsilon_{0}=8.85 \cdot 10^{-12} \mathrm{~F} / \mathrm{m}$, and parameter $\alpha$ characterises distribution of relaxation time $\tau$ values $(0 \leq \alpha<1)$

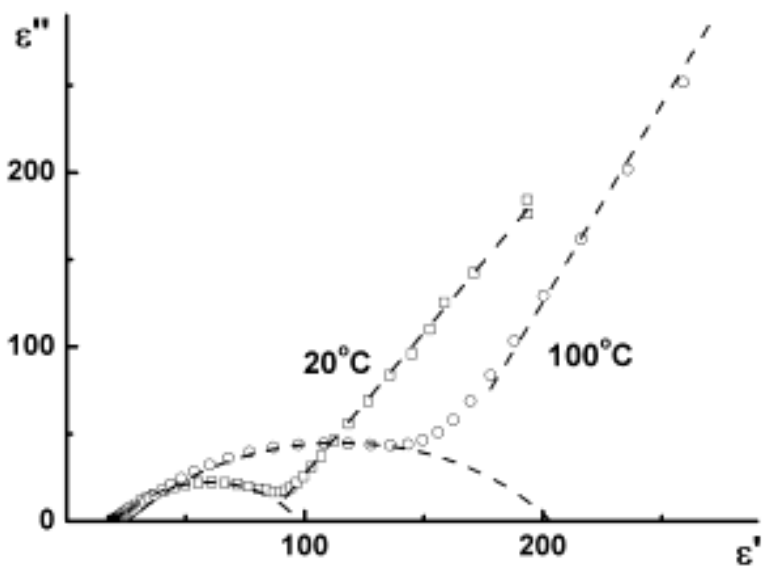

Fig. 2. Cole-Cole plots obtained from room temperature data for the sapropel samples after heat treatment at $\mathrm{t}=20^{\circ} \mathrm{C}$ and $\mathrm{t}=100^{\circ} \mathrm{C}$.

If $\alpha=1$, formulae (1) and (2) reduce to the wellknown Debye expressions, and $\varepsilon^{\prime \prime}=\mathrm{F}\left(\varepsilon^{\prime}\right)$ graph transforms to the semicircle, its centre lying in the $\varepsilon^{\prime}-$ axis. As could be seen from Fig. 2, it does not take place for the sapropel samples under study: the centres of their Cole-Cole semicircles are down shifted along the $\varepsilon$ "- axis. The estimated values of distribution parameter are $\alpha_{20} \approx 0.3, \alpha_{100} \approx 0.4$ for the sapropel samples annealed at $20^{\circ} \mathrm{C}$ and $100^{\circ} \mathrm{C}$, respectively.

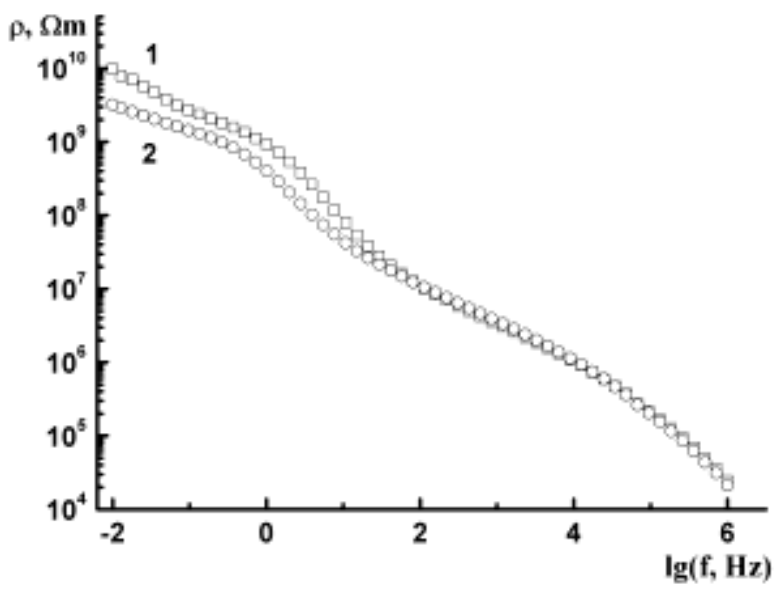

Fig. 3. Frequency dependences of the specific electrical resistance measured at room temperature for the sapropel samples after heat treatment at $\mathrm{t}=20^{\circ} \mathrm{C}$ (curve 1 ) and $\mathrm{t}=100^{\circ} \mathrm{C}$ (curve 2) 
Environment. Technology. Resources, Rezekne, Latvia Proceedings of the $11^{\text {th }}$ International Scientific and Practical Conference. Volume III, 200-206

At low frequencies $(\mathrm{f}<3 \mathrm{~Hz}$ and $\mathrm{f}<1 \mathrm{~Hz}$ for the sapropel samples annealed at $20^{\circ} \mathrm{C}$ and $100^{\circ} \mathrm{C}$, respectively) Cole-Cole plots demonstrate linear dependences $\varepsilon^{\prime \prime}=k \cdot \varepsilon^{\prime}+b$ (straight lines in Fig. 2). This effect can be interpreted as the manifestation of the universal relaxation power law proposed by Jonscher [5], as well as the predominance of DC conductivity contribution in formula (2) at low frequencies.
Figure 3 demonstrates frequency dependences of the specific electrical resistance of the sapropel samples measured at room temperature and gives one more confirmation of this universal relaxation power law: one can see few linear parts in this doublelogarithmic plot. Similar result was published earlier in [6].

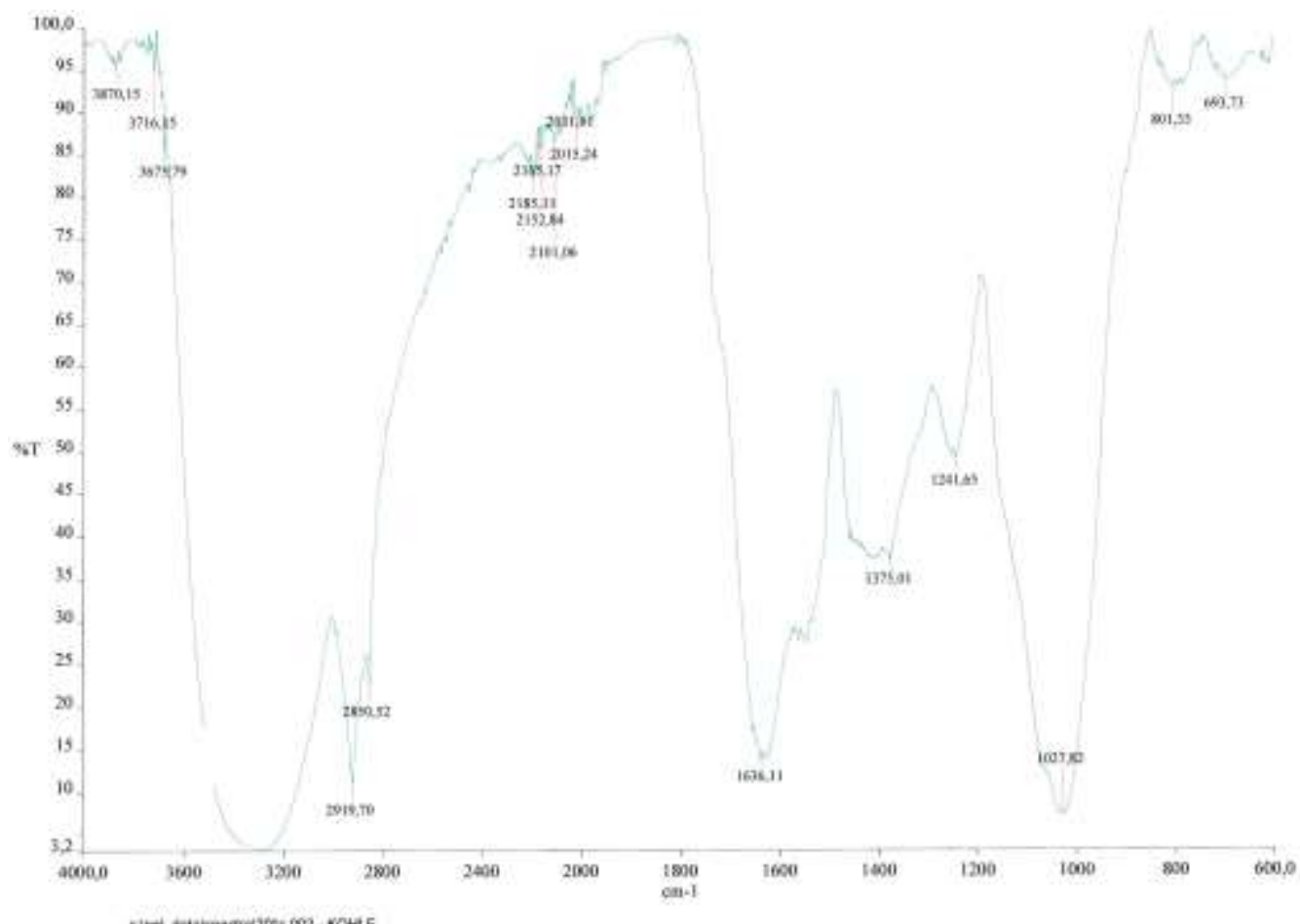

Fig. 4. Infrared spectra of the sapropel sample after heat treatment at $t=20^{\circ} \mathrm{C}$

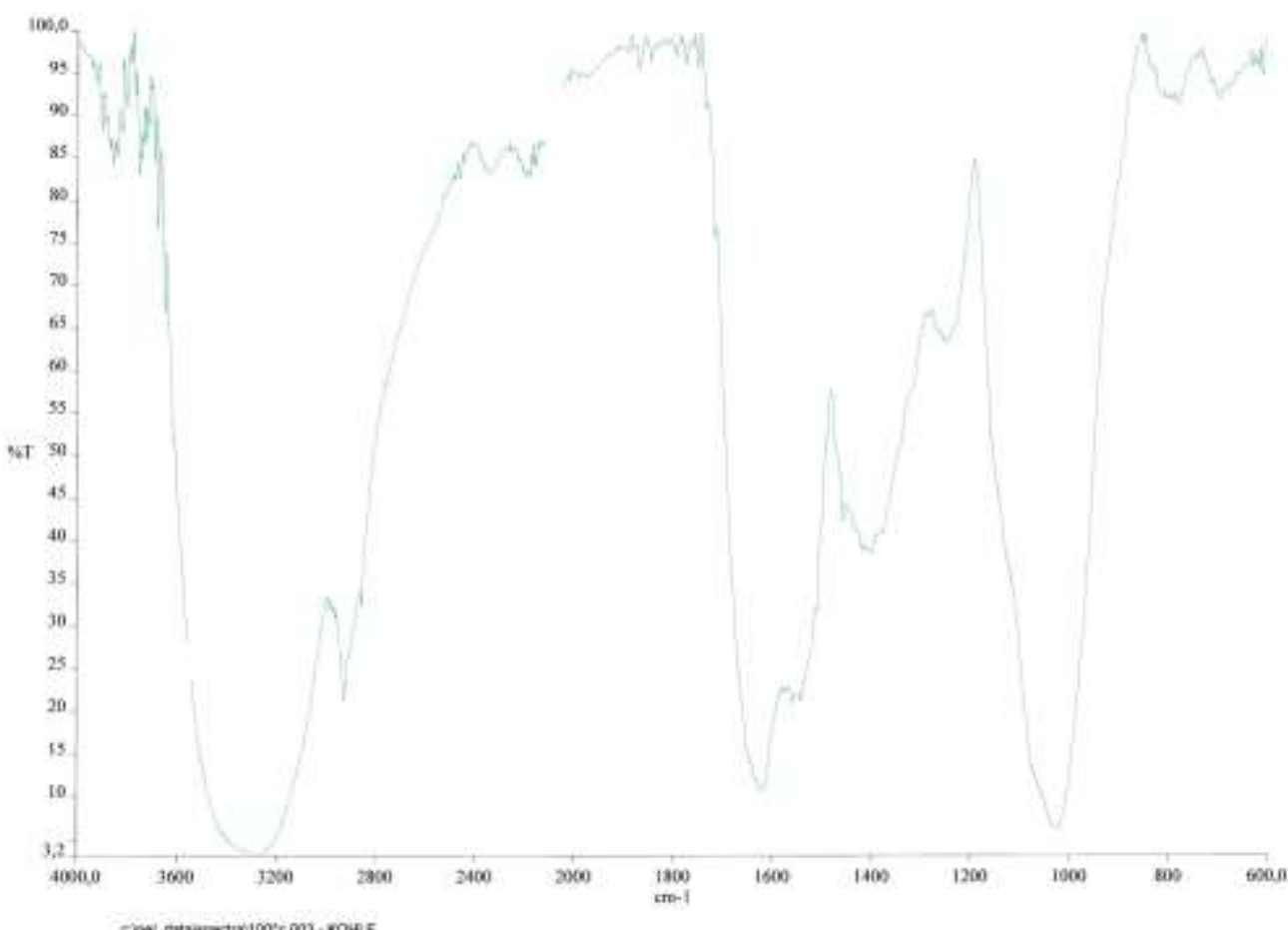

Fig. 5. Infrared spectra of the sapropel sample after heat treatment at $\mathrm{t}=100^{\circ} \mathrm{C}$ 
It should be emphasized that after the heat treatment at $\mathrm{t}=100^{\circ} \mathrm{C}$ specific electrical resistance of the sapropel sample at low frequencies decreases (see curves 1 and 2 in Fig. 3). We suppose that this effect may be due to the sample dehydration during annealing at high temperature. Indeed, the spectral position of the strongest absorption band in the infrared spectra of the initial sapropel sample $\left(3400 \mathrm{~cm}^{-1}\right)$ corresponds to the vibrations of the $\mathrm{OH}^{-}$groups (Fig. 4-5)

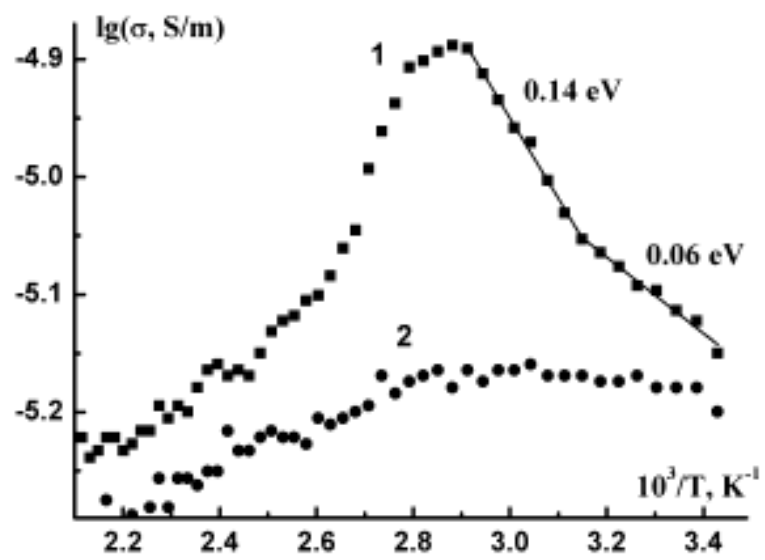

Fig. 6. Arrhenius temperature dependences of the AC electrical conductivity measured twice (curve 1 - first heating, curve 2 second heating) at $\mathrm{f}=1 \mathrm{kHz}$ for the sapropel sample after annealing

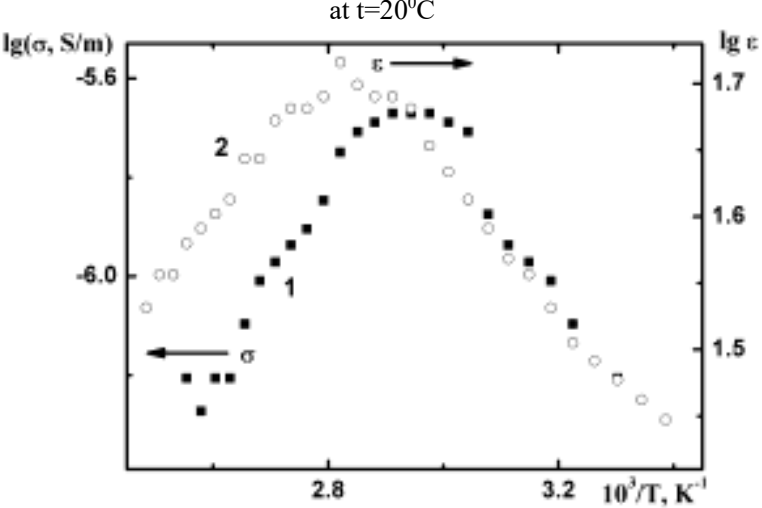

Fig. 7. Arrhenius temperature dependences of the AC electrical conductivity (curve 1) and dielectric permittivity (curve 2) measured

at $\mathrm{f}=1 \mathrm{kHz}$ for the sapropel sample after annealing at $\mathrm{t}=100^{\circ} \mathrm{C}$

Temperature dependences of the AC electrical conductivity $\sigma$ of sapropel samples (Fig. 6-7) also agree with this assumption. During the first heating of the sapropel sample annealed at $\mathrm{t}=20^{\circ} \mathrm{C}$ Arrhenius dependence $\sigma=\sigma_{0} \cdot \exp (-\mathrm{E} /(\mathrm{k} \cdot \mathrm{T}))$ occurs up to the temperature $\mathrm{T}_{0} \approx(345-355) \mathrm{K}$; activation energy $\mathrm{E}$ values for two observed regions (curve 1, Fig. 6) are $0.06 \mathrm{eV}$ and $0.14 \mathrm{eV}$, respectively. Further heating of the sample (when $\mathrm{T}>\mathrm{T}_{0}$ ) results in the conductivity decrease, probably, due to removal of water molecules from the sample. During subsequent cooling of the sample only Arrhenius decrease of conductivity $\sigma$ with activation energy $\mathrm{E}=0.06 \mathrm{eV}$ can be observed. Dehydration of the sapropel sample seems to be irreversible: the second heating (after 4 days storage under the ambient conditions) does not reproduce the initial result (curve 2 in Fig. 6 demonstrates much lower conductivity value and much weaker maximum at $\mathrm{T} \approx \mathrm{T}_{0}$ as compared with characteristic features of curve 1). Analogous phenomena (when sapropel electrical characteristics "remember" sample prehistory) were previously observed in [6] and were treated as "memory" effect.

AC electric conductivity and dielectric permittivity values of the sapropel sample annealed at $\mathrm{t}=100^{\circ} \mathrm{C}$ demonstrate similar behaviour (Fig. 7), but corresponding values are smaller than those of the sapropel sample annealed at $\mathrm{t}=20^{\circ} \mathrm{C}$ (see Fig. 6-7).

Similar results were obtained when the temperature dependence of DC electric conductivity was measured (Fig. 8), but the activation energy value during sample cooling was found to be much larger (about $1.5 \mathrm{eV}$ ). Remarkably, the sample mass value after heating during electrical conductivity measurements decreases probably due to water removal from the pores of this natural adsorbent.

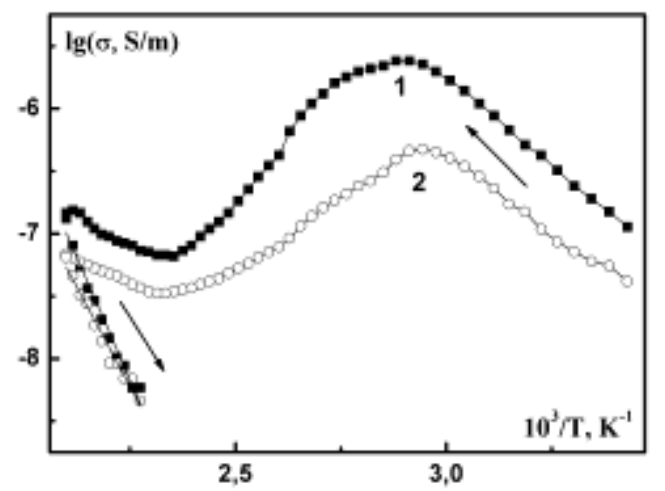

Fig. 8. Arrhenius temperature dependences of the DC electrical conductivity for the sapropel samples after annealing at the temperatures $\mathrm{t}_{1}=50^{\circ} \mathrm{C}$ (curve 1 ) and $\mathrm{t}_{2}=150^{\circ} \mathrm{C}$ (curve 2). Arrows indicate heating and cooling of the samples.

Thus, observed effect of humidity on the electrical properties of sapropel samples allows concluding noticeable ionic contribution into charge transport processes in these substances at low frequencies. It should be noted that our attempts to measure thermal electromotive force of sapropel samples were not successful: no evidence for electronic conduction in these solid dielectrics has been observed.

Mechanical properties of solid sapropel (ultimate compression strength, ultimate strain, Young's modulus) were explored in work [6]. In this paper hardness from Shore D (after heat treatment) dependent on heat treatment temperature was studied - see results in Fig. 9. At temperatures below $100^{\circ} \mathrm{C}$ hardness practically doesn't change, while in the temperature range $100-150^{\circ} \mathrm{C}$ the observed hardness decreases by $5.4 \%$ - probably due to the destruction of $\mathrm{C}-\mathrm{C}, \mathrm{C}=\mathrm{C}$ molecular bonds and the starting of the sapropel destruction process at high temperatures. 
Environment. Technology. Resources, Rezekne, Latvia Proceedings of the $11^{\text {th }}$ International Scientific and Practical Conference. Volume III, 200-206

IR spectra of the samples (see Figs. 4-5), show that the main chemical bonds of sapropel are O-H, C$\mathrm{C}, \mathrm{C}-\mathrm{H}, \mathrm{C}=\mathrm{N}, \mathrm{C}=\mathrm{C}$ with valence oscillations and $\mathrm{CH}_{3}$ with deformation oscillations [9]. Figure 10 demonstrates IR transparency $\mathrm{T}$ dependence on the heat treatment temperature. Supposing, that the number of bonds is proportional to $(1-\mathrm{T})$ value, then at temperature range $100-150^{\circ} \mathrm{C}$ the number of $\mathrm{C}=\mathrm{C}$ bonds decreases by $6.3 \pm 0.1 \%$, the number of $\mathrm{C}=\mathrm{N}$ bonds decreases by $2.2 \pm 0.1 \%$, the number of $\mathrm{C}-\mathrm{C}$ bonds decreases by $1,7 \pm 0.1 \%$, the number of $\mathrm{C}-\mathrm{H}$ bonds increases by $18.5 \pm 0.3 \%$; however the number of $\mathrm{O}-\mathrm{H}$ bonds doesn't change. It means that the humidity of the material during IR spectra capturing is constant.

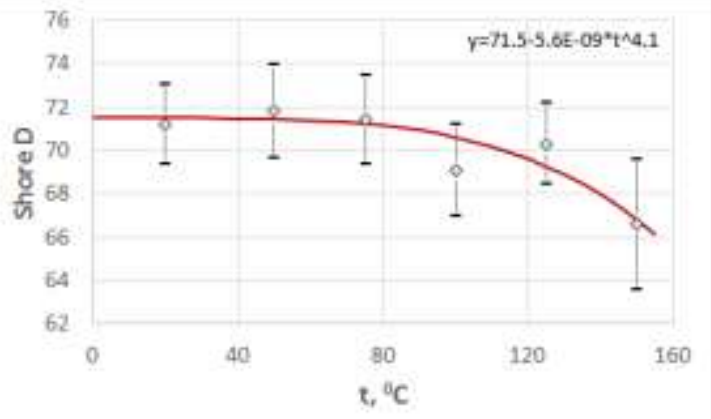

Fig. 9. Shore D hardness dependent on heat treatment (20 min) temperature (after heat treatment)

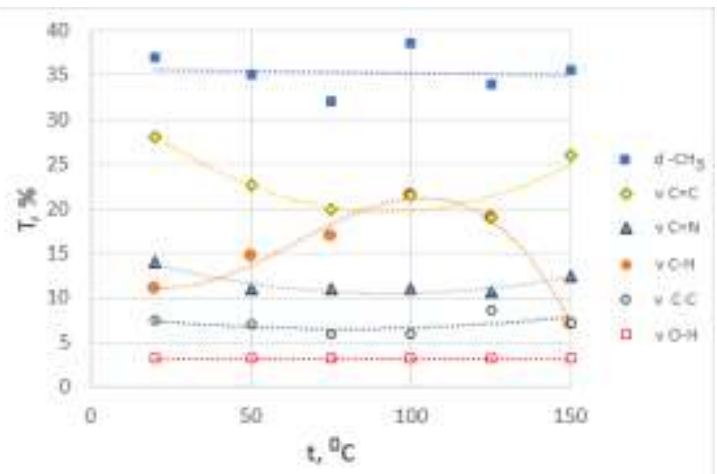

Fig.10. IR transparency $\mathrm{T}$ dependent on heat treatment (20 min) temperature (after heat treatment); v- valence oscillations, $d$ -

deformation oscillations; measurement error $\Delta \mathrm{T}=0,5 \%$

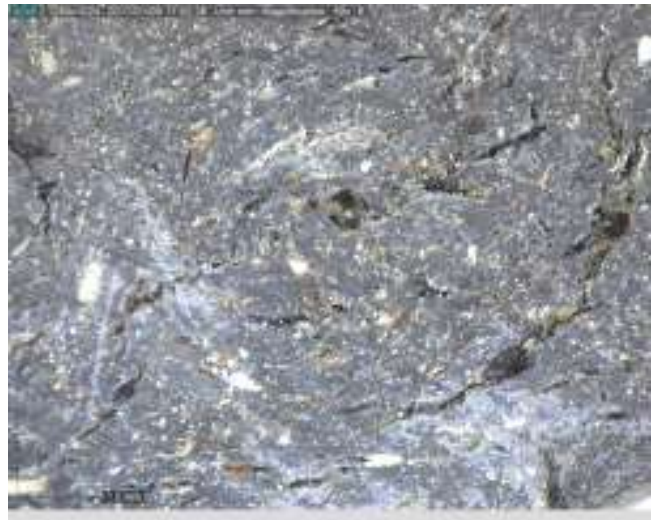

Fig.11. Sapropel structure (polished surface) after heat treatment at $\mathrm{t}=20^{\circ} \mathrm{C}$
Structure of sapropel is highly inhomogeneous with different compositions, many cracks are observed (see Figs.11-12). Different diameter spherical imprints that left by Shore D indenter, reveal about highly different composition. At temperature range $20-150^{\circ} \mathrm{C}$ visual changes of structure were not detected. If indenter gets in crack, then hardness measurer shows lower value. This explains significantly large scatter of results (measurement error) in hardness measuring (Fig.9).

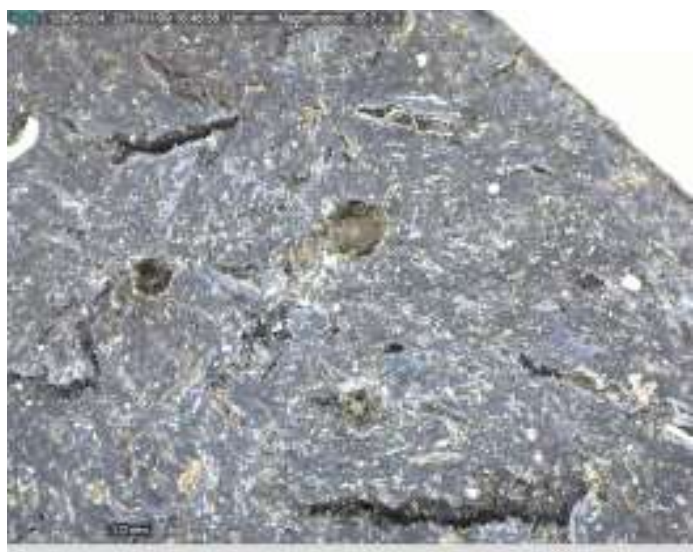

Fig.12. Sapropel structure after $20 \mathrm{~min}$ heat treatment at $\mathrm{t}=150^{\circ} \mathrm{C}$

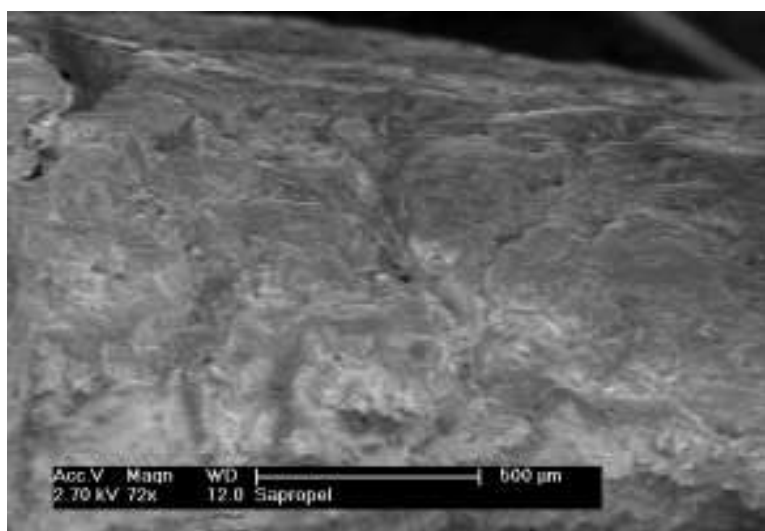

Fig.13. Surface of solid sapropel after heat treatment at $\mathrm{t}=20^{\circ} \mathrm{C}$

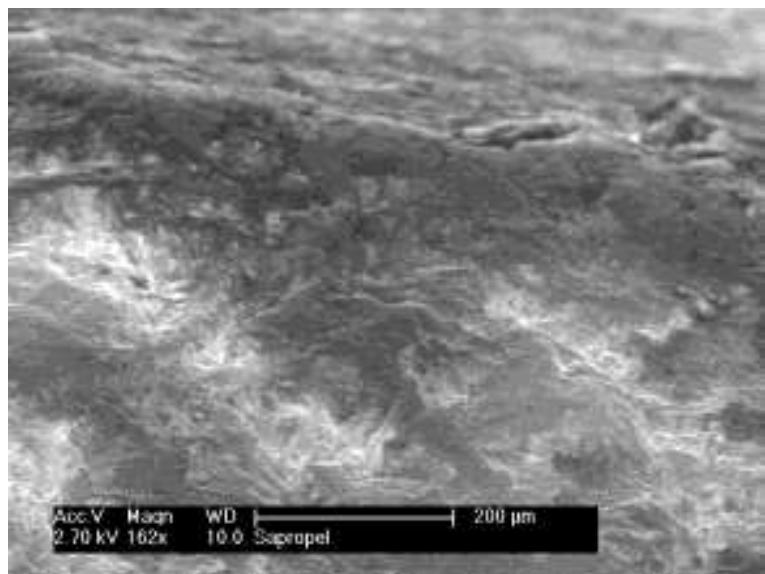

Fig.14. Surface of solid sapropel after $20 \mathrm{~min}$ heat treatment at $\mathrm{t}=150^{\circ} \mathrm{C}$

Comparing SEM images of sapropel surface (Figs. 13 and 14) it is obvious that structure doesn't 
change at the temperature range $20-150^{\circ} \mathrm{C}$. Ascertained, that high porosity presents in the solid sapropel. This is shown by SEM tests, for example, in order to create corresponding SEM vacuum for $1 \mathrm{~cm}^{3}$ sample, period of $2.5 \mathrm{~h}$ is necessary. Considering also that in this material microorganisms develop very well [26], the solid sapropel can be used as biological container for transportation of microorganisms.

We did not detect any changes of chemical composition after heat treatment of the solid sapropel at the temperature of $150^{\circ} \mathrm{C}-$ see chemical composition of given solid sapropel in table 1 .

Table 1.

Chemical composition of solid sapropel

\begin{tabular}{|l|r|r|}
\hline \multirow{3}{*}{$\begin{array}{c}\text { Chemical } \\
\text { elements }\end{array}$} & $\mathrm{T}=20^{\circ} \mathrm{C}$ & \multicolumn{1}{c|}{$\mathrm{T}=150^{\circ} \mathrm{C}$} \\
\cline { 2 - 3 } & \% by weight & \% by weight \\
\hline $\mathrm{O}$ & $45,43 \pm 14,2$ & $44,40 \pm 14,0$ \\
\hline $\mathrm{C}$ & $41,41 \pm 13,2$ & $40,16 \pm 12,9$ \\
\hline $\mathrm{N}$ & $7,47 \pm 2,9$ & $8,19 \pm 3,3$ \\
\hline $\mathrm{Si}$ & $2,02 \pm 0,1$ & $1,97 \pm 0,1$ \\
\hline $\mathrm{Ca}$ & $1,25 \pm 0,1$ & $1,17 \pm 0,1$ \\
\hline $\mathrm{Fe}$ & $1,18 \pm 0,1$ & $2,77 \pm 0,2$ \\
\hline $\mathrm{S}$ & $0,45 \pm 0,0$ & $0,51 \pm 0,0$ \\
\hline $\mathrm{Al}$ & $0,38 \pm 0,0$ & $0,29 \pm 0,0$ \\
\hline $\mathrm{K}$ & $0,21 \pm 0,0$ & $0,20 \pm 0,0$ \\
\hline $\mathrm{Mg}$ & $0,14 \pm 0,0$ & $0,17 \pm 0,0$ \\
\hline $\mathrm{Na}$ & $0,06 \pm 0,0$ & $0,17 \pm 0,0$ \\
\hline
\end{tabular}

\section{CONCLUSION}

In summary, heat treatment has a noticeable effect on the electrical characteristics of solid sapropel due to the strong influence of water on the charge transfer in this complex material. We suppose that electrical properties of sapropel natural sorbents are to some extent similar to those of zeolites (porous dielectric aluminosilicates $[7,8]$ ): in both cases charge transfer occurs predominantly due to ion migration and demonstrates strong dependence upon hydration dehydration processes.

After heat treatment of the solid sapropel at temperatures below $100^{\circ} \mathrm{C}$, its hardness doesn't change. If sample of the solid sapropel is subjected to $20 \mathrm{~min}$ heat treatment at temperature $150^{\circ} \mathrm{C}$, then its hardness decreases by $5.4 \%$, the number of $\mathrm{C}=\mathrm{C}$ bonds decreases by $6.3 \pm 0.1 \%$, the number of $\mathrm{C}=\mathrm{N}$ bonds decreases by $2.2 \pm 0.1 \%$, the number of $\mathrm{C}-\mathrm{C}$ bonds decreases by $1,7 \pm 0.1 \%$, the number of $\mathrm{C}-\mathrm{H}$ bonds increases by $18.5 \pm 0.3 \%$. It shows that in temperature range $100-150^{\circ} \mathrm{C}$ destructive processes of the solid sapropel start, although visually (with optical microscope and with SEM) changes of structure are impossible to observe yet.

\section{REFERENCES}

[1] Поплавко Ю.М., Переверзева Л.П., Раевский И.П. Физика активных диэлектриков (Physics of active dielectrics). Ростов н/Д: Изд-во ЮФУ, 2009. 480 с

[2] Cole K.S., Cole R.H. Dispersion and absorbtion in dielectrics// J. Chem. Phys. 1941. V. 9. P. 341-351.

[3] Богородицкий Н.П., Волокобинский Ю.М., Воробьев А.А., Тареев Б.М. Теория диэлектриков (Theory of dielectrics). М.-Л.: Энергия, 1965. 344 c.
[4] Богатин А.С. Релаксационная поляризация в диэлектриках с большой сквозной электропроводностью (Relaxation polarization in dielectrics with large through conductivity). Автореферат дисс. на соискание ученой степени доктора физ.-мат. наук. Ростов-на-Дону, 2011. 42 c.

[5] Jonscher A.K. Universal relaxation law. London: Chelsea Dielectric Press, 1996. 415 p.

[6] Martinovs A., Timmerberg J., Tretjakova R., Beckmann P., Popa V., Wagner R. Mechanical and electrical properties of the solid sapropel // Environment. Technology. Resources: Proceedings of the 10th International Scientific and Practical Conference. Rezekne, Latvia, 2015, Vol. 1, pp. 139-146.

[7] Breck D.W. Zeolite Molecular Sieves. Wiley: New York, 1974. $782 \mathrm{p}$.

[8] Solovyev V.G., Ivanova M.S., Pan'kova S.V., Trifonov S.V., Veisman V.L. Preparation and physical properties of zeolite, zeolite-like single crystals and zeolite-based nanocomposite materials // Handbook of Zeolites: Structure, Properties and Applications / Editor T.W. Wong. New York: Nova Science Publishers, 2009. Chapter 5. P. 77-99.

[9] Demuth R., Kober F. Grundlagen der Spektroskopie (Gebundene Ausgabe). Verlag: Diesterweg Salle Sauerländer, 1977, 159 Seiten.

[10] P. M. Sivakumar, V.I. Kodolov,G.E. Zaikov, A. K. Haghi. Nanostructure, Nanosystems, and Nanostructured Materials: Theory, Production and Development. Apple Academic Press, Toronto, New Jersey, 2013, pp.580.

[11] Stankevica K., Kḷavins M. Sapropelis un tā izmantošanas iespējas (Sapropel and Its Application Possibilities)// Material Science and Applied Chemistry. 2013 / 29, p.109-126. (in Latvian)

[12] Nikolaeva L. A., Latyshev V. G., Burenina O. N. Fuel Briquettes from Brown Coals of Yakutia. ISSN 0361-5219, Solid Fuel Chemistry, 2009, Vol. 43, No. 2, pp. 109-112.

[13] Kovalenko G. A., Perminova L. V., Terent'eva T. G., Sapunova L. I., Lobanok A. G., Chuenko T. V., Rudina N. A., Chernyak E. I. Glucose Isomerase Activity in Suspensions of Arthrobacter nicotianae Cells and Adsorption Immobilization of the Microorganisms on Inorganic Carriers. Applied Biochemistry and Microbiology, 2008, Vol. 44, No. 2, pp. 174-181

[14] Kovalenko G.A., Perminova L.V., Rudina N.A., Maksimova Yu.G., Maksimov A. Yu. Sapropel-based supports as novel macroporous carbon-mineral adsorbents for enzymatic active substances. Resource-Efficient Technologies, Vol. 2, 2016, pp. 159-167.

[15] Smetanin V. I., Sogin A. V. Use of hydraulic excavation for cleaning and construction of water bodies. Power Technology and Engineering, Vol. 45, No. 4, November, 2011, pp. 254-257.

[16] Перк А. А. Использование сапропелей криолитозоны в качестве источника получения биологически активных веществ гуминового ряда// Перспективы фитобиотехнологии для улучшения качества жизни на Севере: материалы Междунар. конф. с элементами научной школы для молодежи, г. Якутск, Россия, 11-16 окт. 2010 г.- Якутск, 2010. - C. 154-158. (in Russian)

[17] Ядрихинский В. Ф., Перк А. А., Егорова М. С. Применение препарата из сапропеля для лечения демодекоза собак// Актуальные вопросы ветеринарной медицины. - Новосибирск, 2003. - С. 71-72. (in Russian)

[18] Павлова П. А., Перк А. А., Егорова М. С. Влияние биостимулятора из сапропеля на рост и развитие интродуцентов в условиях многолетней мерзлоты// Фундаментальные и прикладные проблемы ботаники в начале XXI века: материалы Bсерос. конф. (Петрозаводск, 22-27 сент. 2008 г.). - Петрозаводск, 2008. - Ч. 6: Экологическая физиология и биохимия растений. Интродукция растений. - С. 291-294. (in Russian)

[19] Juan C. Larrasoana, Andrew P. Roberts, Joseph S. Stoner, Carl Richter, Rolf Wehausen. A new proxy for bottom-water ventilation in the eastern Mediterranean based on diagenetically controlled magnetic properties of sapropel- 
Environment. Technology. Resources, Rezekne, Latvia Proceedings of the $11^{\text {th }}$ International Scientific and Practical Conference. Volume III, 200-206

bearing sediments. Palaeogeography, Palaeoclimatology, Palaeoecology. Vol. 190, 2003, pp. 221-242.

[20] Petrunin G. I., Popov V. G., Soskov A. V. Thermal Properties of the Bottom Sediments of the Black Sea// Moscow University Physics Bulletin, 2008, Vol. 63, No. 1, pp. 61-66.

[21] Adeeva L. N., Kovalenko T. A. Removal of Organic Substances and Metal Ions from Water Using a CarbonMineral Sapropel Sorbent. Russian Journal of Applied Chemistry, 2012, Vol. 85, No. 4, pp. 557-563.

[22] Platonov V. V., Nikolaev D. S., Sakharovskii V. G., Proskuryakov V. A., Nikolaev S. G. High-Resolution ${ }^{1} \mathrm{H}$ NMR Spectroscopy of Organic Matter of Carbonate-Chara Sapropel. Russian Journal of Applied Chemistry, Vol. 75, No. 12, 2002, pp. 2021-2026

[23] Vysokogorskii V. E., Nozdrunova A. A., Plaksin G. V., Krivonos O. I., Mkrtchan O. Z., Petrosyan L. Yu. Antioxidant activity of liquid products of heat-treated sapropels.
Pharmaceutical Chemistry Journal, Vol. 43, No. 4, 2009, pp. 191-194.

[24] Giedrius Balčiūnas, Jadvyga Žvironaite, Sigitas Vejelis, Aleksandras Jagniatinskis,Sergejus Gaidučis. Ecological, thermal and acoustical insulating composite from hempshives and sapropel binder. Industrial Crops and Products, Vol. 91, 2016, pp. 286-294.

[25] Arūnas Kremensas, Rūta Stapulioniene, Saulius Vaitkus, Agne Kairyte. Investigations on physical-mechanical properties of effective thermal insulation materials from fibrous hemp. Procedia Engineering, Vol. 172, 2017, pp. 586-594.

[26] Tretjakova R., Grebeža J., Martinovs A. Research into biological characterictics of dried sapropel// Environment. Technology. Resources: proceedings of the 10th International Scientific and Practical Conference, Rezekne, 2015, Vol. 1, pp. 223-227. 